\title{
Fruit yield and composition in orange trees cv. 'Lane Late' in response to nitrogen fertilization in Sandy Typic Hapludalf soil
}

\author{
Gustavo Brunetto ${ }^{1^{*}}$ Cesar Cella $^{1}{\text { Alcione } \text { Miotto }^{1} \text { Eduardo Girotto }}^{2}$ Felipe Lorensini $^{3}$ \\ Auri Brackmann ${ }^{4}$ Carlos Alberto Ceretta ${ }^{1}$ Márcio Renan Weber Schorr ${ }^{4}$ \\ Vanderlei Both $^{4}$ Vítor Gabriel Ambrosini ${ }^{5}$
}

${ }^{1}$ Departamento de Solos, Programa de Pós-Graduação em Ciência do Solo (PPGCS), Universidade Federal de Santa Maria (UFSM), 97105-900, Santa Maria, RS, Brasil. E-mail: brunetto.gustavo@gmail.com. *Corresponding author.

${ }^{2}$ Instituto Federal de Educação, Ciência e Tecnologia do Rio Grande do Sul (IFRS), Ibirubá, RS, Brasil.

${ }^{3}$ Associação Riograndense de Empreendimentos de Assistência Técnica e Extensão Rural (EMATER), Palmeira das Missões, RS, Brasil.

${ }^{4}$ Departamento de Fitotecnia, Programa de Pós-Graduação em Agronomia, Universidade Federal de Santa Maria (UFSM), Santa Maria, RS, Brasil. ${ }^{5}$ Programa de Pós-Graduação em Ciência do Solo (PPGCS), Universidade Federal do Rio Grande do Sul (UFRGS), Porto Alegre, RS, Brasil.

ABSTRACT: Little is known about the impact of $N$ fertilization on fruit production and composition in orange groves grown in soils with low or medium organic matter content in Rio Grande do Sul (RS). This study aimed to evaluate how N fertilization of orange trees cv. 'Lane Late' in a sandy soil may interfere in fruit yield and composition of fruit and juice. The experiment was conducted with orange trees cv. 'Lane Late' growing in Sandy Typic Hapludalf soil, in Rosário do Sul (RS). The plants received applications of 0, 20, 40, 60, 80, 100, 120, 140 and 160kg $N \mathrm{ha}^{-1}$. Total $\mathrm{N}$ in leaves, number of fruits per plant, yield, fresh weight, fruit diameter, peel thickness, percentage of fruit juice, peel color, juice color, ascorbic acid content, total soluble solids (TSS) and total titratable acidity were evaluated in 2010/2011 and 2011/2012 crops. In the first crop, especially yield, number of fruits per plant, TSS content in fruit juice and ratio decreased with increasing $N$ rate applied. However, in the second crop, the total titratable acidity of the fruit juice prominently increased with the dose of $N$ applied. In both crops, results were highly influenced by rainfall distribution, which affect the plant physiology, soil $N$ dynamics and, consequently, probability of response to $N$ applied and the loss of mineral $N$ in the soil.

Key words: nitrogen, leaf analysis, fruit quality, Citrus sinensis L.

Produção e composição de frutos de laranjeira cv. 'Lane Late' em resposta à adubação nitrogenada em um Argissolo Vermelho

RESUMO: O impacto da adubação nitrogenada na produção e composição de frutos em pomares de laranjeiras cultivados em solos com baixo ou médio teor de matéria orgânica do RS é pouco conhecido. Este trabalho objetivou avaliar como a adubação nitrogenada, em solo de textura arenosa, pode interferir na produção, composição de frutos e do suco em laranjeiras cv. 'Lane Late'. O experimento foi conduzido em um pomar de laranjeiras cv. 'Lane Late' instalado sobre um Argissolo Vermelho, em Rosário do Sul (RS). As plantas foram submetidas à aplicação de 0, 20, 40, 60, 80, 100, 120, 140 e $160 \mathrm{~kg} \mathrm{ha}{ }^{-1}$ de N. Nas safras de 2010/2011 e 2011/2012 foi avaliado o teor total de $\mathrm{N}$ em folhas, o número de frutos por planta, a produção, o peso fresco e diâmetro de frutos, espessura da casca, porcentagem de suco nos frutos, cor da epiderme e do suco, os valores de vitamina C, sólidos solúveis totais (SST) e acidez total titulável. Na primeira safra, especialmente a produção, o número de frutos por planta, o teor de SST no suco e o ratio diminuíram com o aumento da dose de N aplicada. Mas, na segunda safra, de forma destacada, o teor de acidez total titulável no suco aumentou com a dose de N aplicada. Nas duas safras, os resultados foram muito influenciados pela distribuição das precipitações pluviométricas, que afetam a fisiologia da planta, a dinâmica do $N$ no solo e, por consequência, a probabilidade de resposta ao $\mathrm{N}$ aplicado, bem como as perdas de $\mathrm{N}$ mineral no solo.

Palavras-chave: nitrogênio, análise foliar, qualidade do fruto, Citrus sinensis L.

\section{INTRODUCTION}

Brazil is the greatest exporter of citrus juice. In Rio Grande do Sul (RS) State there are approximately 42,000 hectares with citrus crops, accounting for the fifth largest area in the country. From the year 2000, in Rosário do Sul and in other municipalities of the Campanha Gaúcha region, part of the soils with natural grassland were added to the citrus production system, especially sweet orange varieties (Citrus sinensis L.), including cv. 'Lane Late'. This orange cultivar produces fruit that are appreciated for in natura consumption (ALMEIDA et al., 2013). 
Soils in which the groves are planted have a mild rolling relief, facilitating the mechanization of cultural practices. They have a sandy surface horizon and low or medium organic matter content, resulting in a low capacity to supply mineral nitrogen $(\mathrm{N})$ for plants (BRUNETTO et al., 2012). In most of these productive groves, the vegetation on plant rows is desiccation to avoid competition for water and nutrients with orange trees. In general, an intense growth of cover crops is observed in inter-rows. Leguminosae can promote the biological fixation of atmospheric $\mathrm{N}$ together with grasses or other species. They can absorb nutrients, including $\mathrm{N}$, from deeper layers of the soil. With the decomposition of shoot residues deposited on the soil surface and senescent roots inside the soil, the $\mathrm{N}$ contained in the plant tissue can be released to the root zone of orange trees. However, it can be sometimes absorbed in small amounts by plants (DASBERG, 1987). Despite these factors, fully mature leaves, which are organs diagnostic of this nutritional status in orange trees, usually show a total N below "normal status" $\left(<23 \mathrm{~g} \mathrm{~kg}^{-1}\right)$ (CQFS-RS/SC, 2004). Therefore, it usually becomes necessary to apply $\mathrm{N}$ sources, such as urea (BOARETTO et al., 2013).

The amount of $\mathrm{N}$ needed and the dose to be applied in soils of citrus groves, in RS state, are established based on the content of soil organic matter; but the expected yield and the total $\mathrm{N}$ in mature leaves are also considered (CQFS-RS/SC, 2004). However, $\mathrm{N}$ doses have not been established for this culture based on regional calibration experiments in RS. Their impact on the nutritional status of plants, fruit production and its components, such as number of fruits per plant, weight and fruit diameter, are still not known. Effect of $\mathrm{N}$ fertilizer on fruit peel color and juice composition, such as ascorbic acid content, a compound with high reductant power and potential antioxidant activity, have also not been established for this culture (COUTO \& CANNIATTI-BRAZAGA, 2010). Their effects are also unknown regarding total soluble solids (TSS), represented by soluble sugars, organic acids and inorganic salts (WILLS et al., 1981), and the ratio (TSS/acidity), which is used to evaluate fruit ripening and balance of sweet: acid taste; consequently, their effects on the palatability to the consumer (LIMA et al., 1999).

Therefore, it is necessary to carry out calibration experiments in the field in order to obtain numerical parameters that assist in the prediction of $\mathrm{N}$ fertilization. Thereby, it may be possible to establish adequate $\mathrm{N}$ levels to supply the plant demands, increasing fruit yield (CANTARELLA et al., 2003). High levels of $\mathrm{N}$ fertilizer increases fruit weight although dilute the TSS content (FERGUSON \& BOYD, 2002). However, the amount of $\mathrm{N}$ cannot be excessive because, it may stimulate a vegetative growth (PEREIRA et al., 2013), increasing the shading of fruits, which may slow their ripening and the degradation of organic acids. This study aimed to evaluate how nitrogen fertilization of orange trees cv. 'Lane Late', in a sandy soil, which may interfere with the fruit yield and in the composition of fruit and juice.

\section{MATERIALS AND METHODS}

The field experiment started in 2009. The 2010/2011 and 2011/2012 crops, grown in a commercial grove with orange trees cv. 'Lane Late' grafted on a Poncirus trifoliata rootstock in Rosário do Sul (RS), Campanha Gaúcha Central region $\left(30^{\circ} 15^{\prime} 26.75^{\prime}\right.$ S S, 54 $58^{\prime} 43.72$ ' W) (datum WGS84), were evaluated. Grove was established in 2004 , with a $6.0 \mathrm{~m}$ spacing between rows and $3.0 \mathrm{~m}$ between plants, totaling 555 plants per hectare. The climate is humid subtropical (CFA 2). The climatic data observed during the experiment are shown in figure 1. The soil was classified as a Sandy Typic Hapludalf. Prior to the experiment beginning, it was made a soil test (layer $0-20 \mathrm{~cm}$ ). The soil contains $80 \mathrm{~g} \mathrm{~kg}^{-1}$ of clay; $15 \mathrm{~g} \mathrm{~kg}^{-1}$ of organic matter; $\mathrm{pH}$ in water of $5.7 ; 76 \mathrm{mg} \mathrm{dm}^{-3}$ of available $\mathrm{P} ; 80 \mathrm{mg}$ $\mathrm{dm}^{-3}$ of exchangeable $\mathrm{K}$ (Mehlich 1 extractor); $4.4 \mathrm{cmol}_{\mathrm{c}} \mathrm{dm}^{-3}$ of exchangeable $\mathrm{Ca}$ and $0.8 \mathrm{cmol}_{\mathrm{c}}$ $\mathrm{dm}^{-3}$ of exchangeable $\mathrm{Mg}\left(\mathrm{KCl} 1 \mathrm{~mol} \mathrm{~L}^{-1}\right.$ extractor) (TEDESCO et al., 1995).

In September 2009, 2010 and 2011, $0,20,40,60,80,100,120,140$ and $160 \mathrm{~kg} \mathrm{~N} \mathrm{ha}^{-1}$ were applied. Urea $(45 \% \mathrm{~N})$ was used as $\mathrm{N}$ source and was manually applied on the soil surface without incorporation in a circular band with a $1.0 \mathrm{~m}$ width from the stem and in the canopy projection. Application of $\mathrm{N}$ doses was done following the recommendation proposed by CQFS-RS/SC (2004). The experimental design was a randomized block design with three replications, with each plot consisting of five plants. During the experiment, potassium and phosphate fertilization was performed according to CQFS-RS/SC (2004). In August 2011 and 2012, the fruits were harvest. Fruits were picked, quantified and weighed, determining the yield per plant and the average fruit weight. Subsequently, five fruits per plant were randomly selected and taken to the laboratory. Using a digital caliper, the fruit 


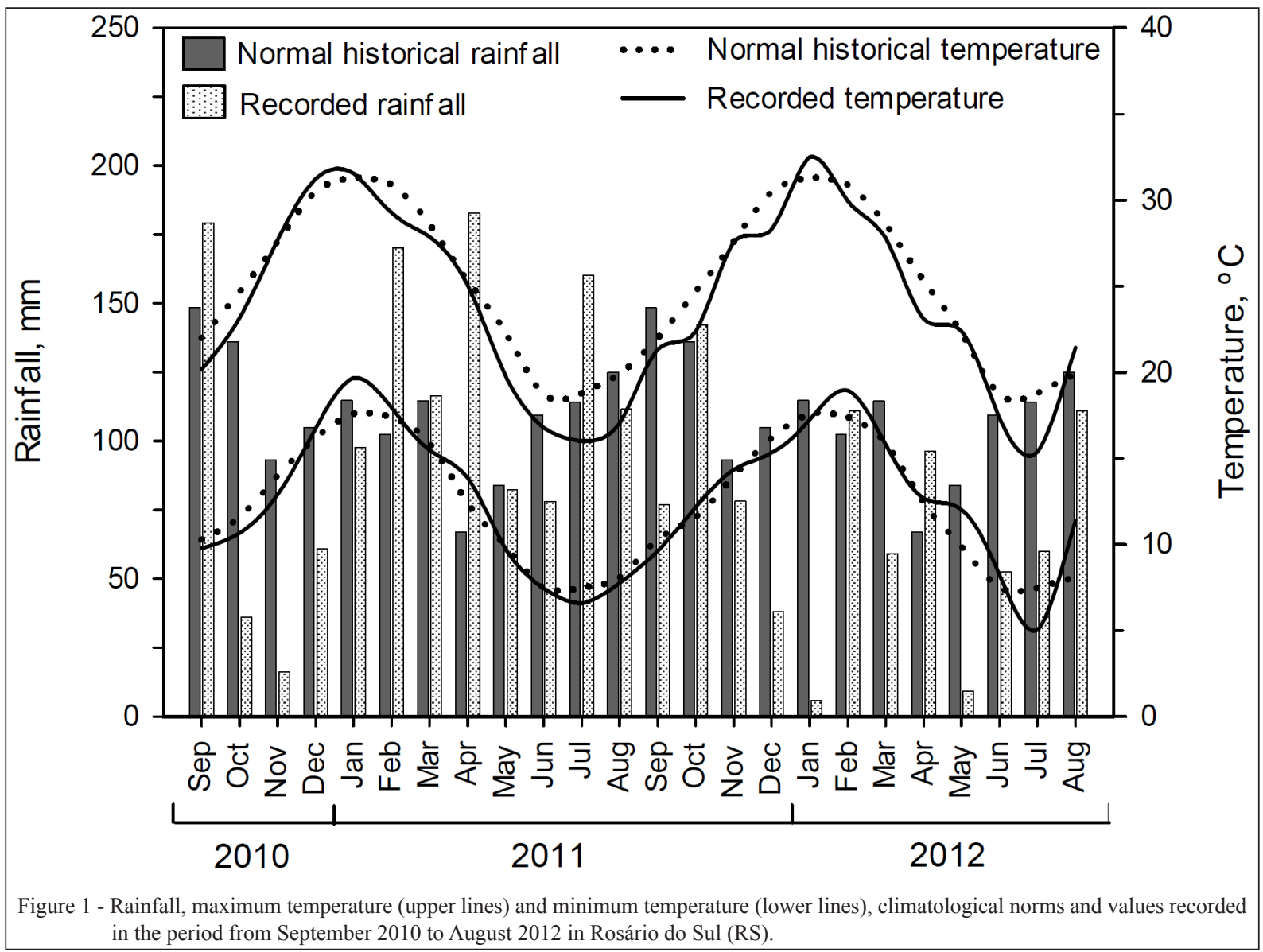

diameter and the peel thickness were determined with two cross-section measurements in each fruit. In the same fruits, the juice was quantified using a juicer. Sample of juice were also analyzed in relation to ascorbic acid content, TSS and total titratable acidity (INSTITUTO ADOLFO LUTZ, 2008). The TSS/ total titratable acidity (ratio) was also calculated.

The epidermis color and the juice color was determined with an electronic colorimeter (Minolta, model CR310), with a three-dimensional color scale $\mathrm{L}^{*} \mathrm{C}^{*} \mathrm{H}^{\circ}$ (CIELAB). The $\mathrm{L}$ value represents lightness scale ranging from black $(\mathrm{L}=0)$ to white $(\mathrm{L}=100)$. The chroma $(\mathrm{C})$ represents the strength of a surface color. At the center of the three-dimensional layout its value is zero and increases as it is moved away. The hue $\left(\mathrm{H}^{\circ}\right)$ is the color tone, wherein the angle $0^{\circ}$ comprises pure red, $90^{\circ}$ pure yellow, $180^{\circ}$ pure green and $270^{\circ}$ blue. Epidermis color was determined in all five fruits in the equatorial region, in less orange and more orange quadrants. Determination of juice color was done in a sample consisting of five fruits. In January, 20 leaves per plant from each crop were collected at approximately $1.5 \mathrm{~m}$ above the ground in four quadrants of the canopy (CQFS$\mathrm{RS} / \mathrm{SC}$, 2004). Leaves were dried, grounded and subjected to analysis of total $\mathrm{N}$ content (TEDESCO et al., 1995). In 2009/2010 season, the amount of rainfall during the flowering was high and affected negatively the yield. Therefore, yield and quality components were not evaluated in this crop season. The data were submitted to analysis of variance (ANOVA) and, when significant, regression equations were adjusted.

\section{RESULTS AND DISCUSSION}

In the 2010/2011 crop season, the fruit yield, number of fruits per plant, TSS of the juice and the ratio decreased with increasing $\mathrm{N}$ doses applied to the soil, presenting low determination coefficients $\left(\mathrm{R}^{2}\right)$, respectively $0.21,0.19,0.44$ and 0.13 (Table 1 ). However, $\mathrm{N}$ doses did not affect fresh fruit weight, fruit diameter, peel thickness, percentage of juice 
Table 1 - Production, yield components, fruit composition and orange fruit juice (cv. 'Lane Late') subjected to N fertilization.

\begin{tabular}{|c|c|c|c|c|c|c|c|c|c|c|}
\hline & \multicolumn{9}{|c|}{ - } & \multirow{2}{*}{$\begin{array}{l}\text { Linear } \\
\text { regression }\end{array}$} \\
\hline & 0 & 20 & 40 & 60 & 80 & 100 & 120 & 140 & 160 & \\
\hline Yield $\left(\mathrm{kg} \mathrm{plant}^{-1}\right)$ & 33.9 & 25.9 & 209 & 30.5 & $11---$ & 244 & 169 & 145 & 169 & $* *(1)$ \\
\hline Number of fruits plant ${ }^{-1}$ & 125.4 & 105.0 & 86.4 & 130.6 & 84.6 & 104.8 & 56.2 & 63.4 & 74.6 & $* *(2)$ \\
\hline Fresh fruit weight $(\mathrm{g})$ & 238.3 & 248.3 & 244.0 & 234.1 & 255.1 & 241.1 & 250.6 & 240.6 & 230.6 & ns \\
\hline Fruit diameter $(\mathrm{cm})$ & 7.82 & 7.78 & 7.80 & 7.77 & 7.81 & 7.74 & 7.73 & 7.71 & 7.64 & ns \\
\hline Peel thickness $(\mathrm{cm})$ & 0.40 & 0.39 & 0.42 & 0.37 & 0.37 & 0.35 & 0.36 & 0.37 & 0.35 & ns \\
\hline Juice (\%) & 49.2 & 49.2 & 48.3 & 48.8 & 48.2 & 48.7 & 49.1 & 48.0 & 48.0 & ns \\
\hline $\mathrm{C}$ vitamin $\left(\mathrm{mg} 100 \mathrm{~mL}^{-1}\right)$ & 45.6 & 45.8 & 46.7 & 53.9 & 50.7 & 48.6 & 45.4 & 52.3 & 49.1 & $\mathrm{~ns}$ \\
\hline TSS ( $\left({ }^{\circ}\right.$ Brix $)$ & 10.6 & 10.7 & 10.3 & 10.1 & 10.1 & 10.3 & 9.8 & 10.0 & 9.7 & $* *(3)$ \\
\hline $\begin{array}{l}\text { Total titratable acidity } \\
\text { citric acid } 100 \mathrm{~mL}^{-1} \text { ) }\end{array}$ & 1.11 & 1.22 & 1.00 & 1.04 & 1.05 & 1.11 & 1.13 & 1.12 & 1.12 & ns \\
\hline Ratio & 9.6 & 8.8 & 10.4 & 9.7 & 9.6 & 9.3 & 8.8 & 8.9 & 8.7 & $*(4)$ \\
\hline Total $\mathrm{N}$ in leaf (\%) & 2.59 & 2.84 & 2.83 & 2.65 & 2.68 & 2.69 & 2.75 & 2.78 & 2.89 & $\mathrm{~ns}$ \\
\hline & & & & ---2011 & 12--- & ---- & 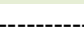 & --- & - & --- \\
\hline Yield $\left(\mathrm{kg} \mathrm{plant}^{-1}\right)$ & 34.0 & 46.0 & 41.6 & 43.5 & 33.2 & 37.1 & 37.5 & 29.8 & 32.4 & ns \\
\hline Number of fruits plant ${ }^{-1}$ & 182.0 & 245.2 & 222.0 & 274.6 & 173.4 & 216.2 & 204.8 & 177.2 & 192.8 & ns \\
\hline Fresh fruit weight $(\mathrm{g})$ & 187.0 & 188.2 & 186.4 & 180.2 & 192.1 & 172.7 & 182.9 & 178.0 & 172.5 & ns \\
\hline Fruit diameter $(\mathrm{cm})$ & 7.20 & 7.36 & 7.28 & 7.30 & 7.28 & 7.24 & 7.36 & 7.18 & 7.08 & ns \\
\hline Peel thickness $(\mathrm{cm})$ & 0.43 & 0.44 & 0.47 & 0.45 & 0.47 & 0.45 & 0.43 & 0.43 & 0.45 & ns \\
\hline Juice (\%) & 51.1 & 51.6 & 50.0 & 51.6 & 50.8 & 51.4 & 50.6 & 51.4 & 51.7 & ns \\
\hline $\mathrm{C}$ vitamin $\left(\mathrm{mg} 100 \mathrm{~mL}^{-1}\right)$ & 63.9 & 64.6 & 66.6 & 65.3 & 63.1 & 65.5 & 62.7 & 65.5 & 69.9 & ns \\
\hline TSS ( ${ }^{\circ}$ Brix $)$ & 14.1 & 12.9 & 14.4 & 12.9 & 13.0 & 13.6 & 12.4 & 12.6 & 12.9 & ns \\
\hline $\begin{array}{l}\text { Total titratable acidity } \\
\text { citric acid } 100 \mathrm{~mL}^{-1} \text { ) }\end{array}$ & ' 0.99 & 1.06 & 0.95 & 1.04 & 1.06 & 1.02 & 1.10 & 1.10 & 1.09 & $* *(5)$ \\
\hline Ratio & 14.3 & 12.9 & 14.4 & 12.9 & 13.0 & 13.6 & 12.4 & 12.6 & 12.9 & $*^{*}(6)$ \\
\hline Total $\mathrm{N}$ in leaf $(\%)$ & 2.57 & 2.58 & 2.71 & 2.62 & 2.60 & 2.74 & 2.74 & 2.74 & 2.67 & ns \\
\hline
\end{tabular}

${ }^{(1)} \mathrm{y}=30.38-0.0997 \mathrm{x}, \mathrm{R}^{2}=0.21 ;{ }^{(2)} \mathrm{y}=128.85-0.4237 \mathrm{x}, \mathrm{R}^{2}=0.19 ;{ }^{(3)} \mathrm{y}=10.63-0.0056 \mathrm{x}, \mathrm{R}^{2}=0.44 ;{ }^{(4)} \mathrm{y}=9.68-0.0052 \mathrm{x}, \mathrm{R}^{2}=0.13 ;{ }^{(5)} \mathrm{y}=0.99+0.0007 \mathrm{x}$, $\mathrm{R}^{2}=0.86 ;{ }^{(6)} \mathrm{y}=13.86-0.0081 \mathrm{x}, \mathrm{R}^{2}=0.14 .{ }^{\mathrm{ns}}$ not significant; ${ }^{* *}$ significant at $1 \%$ error probability; ${ }^{*}$ significant at $5 \%$ error probability.

and total $\mathrm{N}$ content in mature leaves. In addition, juice parameters as ascorbic acid content and total titratable acidity were also not affected. This little expressive answer may be attributed to the fact that in the previous crop season there was not fruit yield due to the high volume of rain in the period. Therefore, for this crop season, the plants had more internal reserves of $\mathrm{N}$ compounds, based on rates of $\mathrm{N}$ in leaves, which minimized the treatments effect (Table 1). In addition, little answer can be attributed in part to the high volume of rainfall in the last months of 2010, and also over some months in 2011 (Figure 1). Because of this, as the soil only had $15 \mathrm{~g} \mathrm{~kg}^{-1}$ of organic matter and $80 \mathrm{~g} \mathrm{~kg}^{-1}$ of clay, part of the $\mathrm{N}$ applied may have been lost by leaching, especially in the $\mathrm{NO}_{3}^{-}-\mathrm{N}$ form. LORENSINI et al. (2012), verified in the same kind of soil present in the study, in an area nearby this experiment, a considerable raise in the concentrations of $\mathrm{NO}_{3}^{-}-\mathrm{N}$ at $20 \mathrm{~cm}$ depth, 20 days after the surface application of urea in the doses of $120 \mathrm{~kg} \mathrm{~N} \mathrm{ha}^{-1}$. This showed the ease in which the $\mathrm{NO}_{3}^{-}-\mathrm{N}$ can migrate in the profile of this soil, even under moderate rain condition.

As for most fruit trees, most roots responsible for absorbing water and nutrients are located in the superficial layers of the soil. If a downward movement of forms of $\mathrm{N}$ into deeper layers of the soil profile happens, a lower utilization of $\mathrm{N}$ applied is expected and, consequently, less accumulation in the organs of the plant (MAUST \& WILLIAMSON, 1994). This may explain in part why there was no increase in the total $\mathrm{N}$ content in leaves and also the impact of $\mathrm{N}$ applied to other evaluated parameters such as fresh fruit weight, fruit diameter, peel thickness, percentage of juice in fruits, vitamin C content and total titratable acidity in the juice.

In addition, DAVIES \& ALBIGO (1994) attribute the low absorption of $\mathrm{N}$ in the early stages 
of budding and flowering (spring) of citrus, a period coinciding with the application of fertilizers, to the decreased activity or the roots. LEGAZ et al. (1995) observed that $70 \%$ of the $\mathrm{N}$ reported in early leaves and branches derived from the plant's internal reserves. Consequently, the increase of the content of $\mathrm{N}$ in the soil increases its losses and decreases the utilization efficiency of $\mathrm{N}$ by plants (DE PAZ \& RAMOS, 2004).

Decrease in TSS contents in fruits derived from plants submitted to application of higher $\mathrm{N}$ doses to the soil is usually attributed to the dilution of sugars, due to the increased weight or fruit diameter, or yet by the competition for assimilates between shoots and fruits (FERGUSON \& BOYD, 2002). It may even have contributed to the dilution of $\mathrm{N}$ inside the plants, since there was no increase of it in their fully mature leaves. This is a possible explanation because there was no statistical increase in weight and fruit diameter (Table 1). There are fluctuations in the average values of $238.3 \mathrm{~g}$ in fruits of plants grown without nitrogen fertilization up to average values above $250 \mathrm{~g}$ in plants grown with the $\mathrm{N}$ application such as those subjected to the addition of 80 to $120 \mathrm{~kg}$ $\mathrm{N}$ ha-1. TSS values correspond mainly to soluble sugars, organic acids and inorganic salts (WILLS et al., 1981). Together with the ratio value, $\mathrm{pH}$ and total titratable acidity, they can be used to evaluate the state of ripening of fruits and the definition of the harvest time. However, also based on TSS values, it can be inferred that the taste of the fruits changed with the dose of $\mathrm{N}$ supplied to the plants, which may affect consumer acceptability.

In the 2011/2012 crop season, the doses of $\mathrm{N}$ applied to the plants did not affect the fruit yield, number of fruits per plant, fresh fruit weight, fruit diameter, peel thickness, juice content, total nitrogen content in leaves, ascorbic acid and TSS content in the juice (Table 1). This might be attributed to the absorption by plants, such as those grown without the addition of $\mathrm{N}$ fertilizer, of $\mathrm{N}$ derived from other sources such as from the $\mathrm{N}$ mineralization soil labile organic matter and from decomposing residues in the inter-row soil surface, such as senescent and pruned leaves and roots inside the soil (BRUNETTO et al., 2011; 2014). This is suggested because there was an adequate distribution of rainfalls, especially during the citrus growing period (Figure 1). This explanation can also be applied to the biological $\mathrm{N}$ fixation made by native leguminosae that cohabited the rows of the grove and to the release of $\mathrm{N}$ contained in its decomposing residue at the soil surface or even in senescent roots inside the soil (DASBERG, 1987).

The total titratable acidity in the juice increased according to the $\mathrm{N}$ dose, which was reflected in ratio values (Table 1). These results further reinforce previous results on vines obtained by BRUNETTO et al. (2007), who attributed this to the shoot vegetative growth, causing an increase in fruit shading inside plants, slowing the ripening and the degradation of organic acids in the fruit. This likely stimulation of shoot vegetative growth according to the increase of the $\mathrm{N}$ dose in the soil may have caused the dilution of $\mathrm{N}$ inside the plant. An increase of its content in mature leaves was not observed (Table 1), as well as in the 2011/2012 crop. Based on these results, it is possible to infer that the fruits of plants subjected to higher $\mathrm{N}$ doses are more acidic.

Regarding fruit peel color, there was a similar response in both crop seasons (2010/2011 and 2011/2012) to chroma parameters (C), which were not influenced by the dose of $\mathrm{N}$ applied, and hue angle $\left(\mathrm{H}^{\circ}\right)$, which increased with higher $\mathrm{N}$ doses (Table 2). The values recorded for $\mathrm{H}^{\circ}$ mean that the fruit epidermis color was between yellow and red. In fruits from plants subjected to the lowest $\mathrm{N}$ doses the epidermis tended more to a red color and plants with the application of the highest doses of $\mathrm{N}$ showed a more yellowish epidermis. In both crop season, the determination coefficient was low $\left(r^{2}=0.10\right)$, meaning that only $10 \%$ of the change in peel color was due to the $\mathrm{N}$ fertilization. However, there was a statistical significance at 5 and $1 \%$ error probability in the first and second crops, respectively. As redder the epidermis color, the higher the chlorophyll degradation, providing conditions for an enhanced expression of carotenoid pigments, since the $\mathrm{N}$ deficiency is associated with premature fruit ripening (MAGALHÃES, 2006). This may explain the lower value of $\mathrm{H}^{\circ}$ in the treatment without $\mathrm{N}$ application or with low doses due to the increased degradation of chlorophyll caused by the advance of fruit maturation. Furthermore, a higher $\mathrm{N}$ content in peels retards the degradation of chlorophyll (HUFF, 1983). The brightness (L) also varied depending on $\mathrm{N}$ rates regarding the peel color of fruits from the 2010/2011 crop. The fruit epidermis of plants without $\mathrm{N}$ application or with lower $\mathrm{N}$ rates had a darker coloring (lower L value). However, fruit epidermis of plants with higher $\mathrm{N}$ rates application had a lighter coloring (Table 2). However, in the 2011/2012 crop, the fruit epidermis color was not affected by the $\mathrm{N}$ application. Another important 
Table 2 - Fruit peel color and orange fruit juice (cv. 'Lane Late') subjected to N fertilization.

\begin{tabular}{|c|c|c|c|c|c|c|}
\hline \multirow{3}{*}{$\mathrm{N}\left(\mathrm{kg} \mathrm{ha}^{-1}\right.$ year $\left.^{-1}\right)$} & \multicolumn{6}{|c|}{ 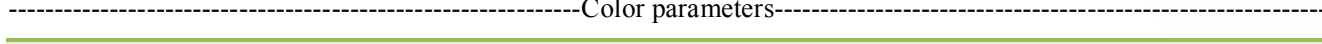 } \\
\hline & \multicolumn{3}{|c|}{ 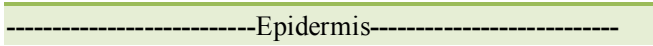 } & \multicolumn{3}{|c|}{ 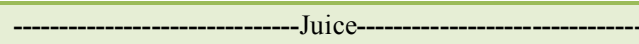 } \\
\hline & $\mathrm{L}$ & $\mathrm{C}$ & $\mathrm{H}^{\mathrm{o}}$ & $\mathrm{L}$ & $\mathrm{C}$ & $\mathrm{H}^{\mathrm{o}}$ \\
\hline 0 & 69.7 & 73.8 & 72.9 & 69.3 & 59.6 & 82.9 \\
\hline 20 & 70.2 & 73.0 & 73.3 & 68.5 & 58.7 & 83.7 \\
\hline 40 & 70.6 & 73.4 & 74.6 & 68.6 & 58.3 & 84.6 \\
\hline 60 & 70.9 & 73.6 & 74.7 & 67.2 & 58.9 & 84.7 \\
\hline 80 & 70.4 & 72.9 & 74.8 & 66.1 & 59.3 & 84.9 \\
\hline 100 & 71.1 & 74.4 & 73.3 & 67.3 & 58.6 & 83.9 \\
\hline 120 & 70.8 & 72.5 & 74.2 & 67.7 & 58.6 & 84.7 \\
\hline 140 & 71.4 & 74.7 & 74.4 & 67.6 & 58.6 & 84.4 \\
\hline 160 & 72.0 & 74.5 & 75.6 & 67.7 & 56.6 & 83.7 \\
\hline Significant & $* *$ & ns & * & ns & ns & $\mathrm{ns}$ \\
\hline Equation & $y=69.9+0.011 x$ & - & $y=73.3+0.011 x$ & - & - & - \\
\hline $\mathrm{r}^{2}$ & 0.33 & - & 0.10 & - & - & - \\
\hline $\mathrm{CV}(\%)$ & 1.23 & 2.50 & 2.34 & 3.11 & 5.13 & 1.58 \\
\hline 0 & 67.1 & 72.5 & 69.1 & 69.3 & 60.4 & 83.4 \\
\hline 20 & 67.1 & 71.9 & 70.4 & 69.9 & 62.8 & 83.4 \\
\hline 40 & 67.7 & 73.6 & 69.8 & 70.8 & 62.0 & 84.0 \\
\hline 60 & 68.2 & 72.0 & 72.1 & 70.3 & 63.2 & 83.8 \\
\hline 80 & 67.4 & 73.2 & 71.3 & 70.2 & 61.9 & 82.9 \\
\hline 100 & 67.3 & 72.2 & 69.7 & 70.3 & 62.1 & 83.5 \\
\hline 120 & 67.7 & 72.1 & 70.4 & 69.9 & 63.0 & 83.4 \\
\hline 140 & 68.4 & 70.5 & 72.4 & 69.9 & 61.6 & 83.1 \\
\hline 160 & 67.9 & 71.4 & 71.3 & 70.7 & 60.7 & 83.1 \\
\hline Significant & ns & ns & ** & ns & ns & ns \\
\hline Equation & - & - & $y=69.8+0.012 x$ & - & - & - \\
\hline$r^{2}$ & - & - & 0.10 & - & - & - \\
\hline $\mathrm{CV}(\%)$ & 2.58 & 2.16 & 2.40 & 1.41 & 2.55 & 0.70 \\
\hline
\end{tabular}

${ }^{\text {ns }}$ not significant; ${ }^{* *}$ Significant at $1 \%$ error probability; ${ }^{*}$ Significant at $5 \%$ error probability.

parameter of fruit quality, i.e., juice color, was not altered by the $\mathrm{N}$ fertilization in both crops.

\section{CONCLUSION}

In the first crop, especially fruit yield, number of fruits per plant, TSS content in fruit juice and ratio decreased with increasing $\mathrm{N}$ rate applied in orange trees cv. 'Lane Late'. However, in the second crop, the total titratable acidity of the fruit juice prominently increased with the higher $\mathrm{N}$ rates applied. In both crops, the results were highly influenced by rainfall distribution, which affected the plant physiology, soil $\mathrm{N}$ dynamics and consequently the probability of response to $\mathrm{N}$ applied and the loss of mineral $\mathrm{N}$ in the soil.

\section{ACKNOWLEDGEMENTS}

The authors thanks Conselho Nacional de Desenvolvimento Científico e Tecnológico (CNPq) for its financial support. The first, sixth and seventh authors thank the CNPq for research grants.

\section{REFERENCES}

ALMEIDA, S.C. et al. Economic analysis of citrus Rosário do Sul/RS: a focus on the adoption of environmental certification program. Revista Eletrônica em Gestão, Educação e Tecnologia Ambiental, v.11, p.2427-2436, 2013. Available from: <http:/ dx.doi.org/10.5902/223611708803>. Accessed: May 05, 2015. doi: $10.5902 / 223611708803$.

BOARETTO, R.M. et al. Absorption of ${ }^{15} \mathrm{NH}_{3}$ volatilized from urea by Citrus trees. Plant and Soil, v.365, p.283-290, 2013. Available from: 
$<$ http:/dx.doi.org/10.1007/s11104-012-1380-7>. Accessed: Nov. 18, 2016. doi: 10.1007/s11104-012-1380-7.

BRUNETTO, G. et al. Application of nitrogen in grapevines in the campaign of the Rio Grande do Sul: productivity and chemical characteristics of the grape must. Ciência Rural, v.37, p.389393, 2007. Available from: <http://dx.doi.org/10.1590/S010384782007000200014>. Accessed: May 04, 2014. doi: 10.1590/ S0103-84782007000200014.

BRUNETTO, G. et al. Nutrients release during the decomposition of mowed perennial ryegrass and white clover and its contribution to nitrogen nutrition of grapevine. Nutrient Cycling in Agroecosystems, v.90, p.299-308, 2011. Available from: <http:/ dx.doi.org/10.1007/s10705-011-9430-8>. Accessed: Nov. 18, 2016. doi: 10.1007/s10705-011-9430-8.

BRUNETTO, G. et al. Use of the SPAD-502 in estimating nitrogen content in leaves and yield in grapevines in soils with different texture. American Journal of Plant Sciences, v.3, p.1546-1561, 2012. Available from: <http:/dx.doi.org/10.4236/ ajps.2012.311187>. Accessed: Nov. 18, 2016. doi: 10.4236/ ajps.2012.311187.

BRUNETTO, G. et al. Contribution of nitrogen from agricultural residues of rye to 'Niagara Rosada' grape nutrition. Scientia Horticulturae, v.169, p.66-70, 2014. Available from: <http:/ dx.doi.org/10.1016/j.scienta.2014.02.019>. Accessed: Nov. 18, 2016. doi: 10.1016/j.scienta.2014.02.019.

CANTARELLA, $H$. et al. Fruit yield of 'Valencia' sweet orange fertilized with different $\mathrm{N}$ sources and the loss of applied N. Nutrient Cycling in Agroecosystems, v.67, p.215-223, 2003. Available from: <http:/dx.doi.org/10.1023/ B:FRES.0000003600.20499.76>. Accessed: Nov. 18, 2016. doi: 10.1023/B:FRES.0000003600.20499.76.

COMISSÃO DE QUÍMICA E FERTILIDADE DO SOLO - RS SC. Manual de adubação e calagem para os Estados do Rio Grande do Sul e de Santa Catarina. 10.ed. Porto Alegre: SBCS - Núcleo Regional Sul/UFRGS, 2004. 400p.

COUTO, M.A.L.; CANNIATTI-BRAZACA, S.G. Quantification of vitamin $\mathrm{C}$ and antioxidant capacity of citrus varieties. Ciência e Tecnologia de Alimentos, v.30, p.15-19, 2010. Available from: $\quad<$ http://dx.doi.org/10.1590/S0101-20612010000500003>. Accessed: May 04,2014.doi: 10.1590/S0101-20612010000500003.

DASBERG, S. Nitrogen fertilization in citrus orchards. Plant and Soil, v.100, p.1-9, 1987. Available from: <http:/dx.doi. org/10.1007/BF02370928>. Accessed: Nov. 18, 2016. doi: $10.1007 / \mathrm{BF} 02370928$.

DAVIES, F.S.; ALBIGO L.G. Citrus. 2.ed. Wallingford: CAB international, 1994. 254p.

DE PAZ, J.M.; RAMOS, C. Simulation of nitrate leaching for different nitrogen fertilization rates in a region of Valencia
(Spain) using a Gis-Gleams system. Agriculture, Ecossystems \& Environment, v.103, p.59-73, 2004. Available from: $<$ http:/dx.doi. org/10.1016/j.agee.2003.10.006>. Accessed: Nov. 18, 2016. doi: 10.1016/j.agee.2003.10.006.

FERGUSON, I.B.; BOYD, L.M. Inorganic nutrients and fruit quality. In: KNEE, M. Fruit quality and its biological basis. Ohio: Wiley Blackwell, 2002. Cap.2, p.17-45.

HUFF, A. Nutritional control of regreening and degreening in citrus peel segments. Plant Physiology, v.73, p.243-249, 1983. Available from: <http:/dx.doi.org/10.1104/pp.73.2.243>. Accessed: Nov. 18, 2016. doi: 10.1104/pp.73.2.243.

INSTITUTO ADOLFO LUTZ. Métodos físico-químicos para análise de alimentos. São Paulo: Instituto Adolfo Lutz, 2008. 1020p.

LEGAZ, F. et al. Mobilization of the reserve $\mathrm{N}$ in citrus. Plant and soil, v.173, p.205-210, 1995. Available from: $<\mathrm{http} / \mathrm{dx}$.doi. org/10.1007/BF00011457>. Accessed: Nov. 18, 2016. doi: 10.1007/BF00011457

LIMA, L.C. et al. Quality of the 'Ponkan' tangerine tree fruits (Citrus reticulata Blanco), stored at room temperature. Revista da Universidade de Alfenas, v.5, p.27-31, 1999. Available from: $<$ http://www.unifenas.br/pesquisa/download/ArtigosRev1_99/ pag27-31.pdf>. Accessed: Nov. 18, 2016.

LORENSINI, F. et al. Lixiviation and volatilization of nitrogen in Sandy Typic Hapludalf soil cultivated with grapevine submitted to the nitrogen fertilization. Ciência Rural, v.42, p.11731179, 2012. Available from: <http://dx.doi.org/10.1590/S010384782012005000038>. Accessed: Jun. 08, 2016. doi: 10.1590/ S0103-84782012005000038.

MAGALHÃES, A.F. de J. Nutrição mineral e adubação dos citros irrigados. Cruz das Almas: EMBRAPA, 2006. 12p. (Circular Técnica 79)

MAUST, B.E.; WILLIAMSON, J.G. Nitrogen nutrition of containerized citrus nursery plants. American Society for Horticultural Science, v.119, p.195-201, 1994. Available from: $<$ http://journal.ashspublications.org/content/119/2/195.full.pdf $>$. Accessed: Nov. 18, 2016.

PEREIRA, I.S. et al. Nitrogen fertilization and agronomic characteristics in blackberry. Pesquisa Agropecuária Brasileira, v.48, p.373-380, 2013. Available from: <http://dx.doi.org/10.1590/ S0100-204X2013000400004>. Accessed: May 04, 2014. doi: 10.1590/S0100-204X2013000400004

TEDESCO, M.J. et al. Análises de solo, plantas e outros materiais. Porto Alegre: UFRGS/Departamento de Solos, 1995. 174 p. (Boletim Técnico 5).

WILLS, R.H.H. et al. Postharvest: an introduction to the physiology and handling of fruit and vegetables. Westport: AVI, 1981. 163p. 